\title{
HUBUNGAN KOMPONEN HEALTH BELIEF MODEL DENGAN UPAYA PENCEGAHAN INFEKSI MENULAR SEKSUAL PADA IBU RUMAH TANGGA MELALUI PENGGUNAAN KONDOM
}

\author{
Silvia Ari Agustina \\ ${ }^{1}$ Silvia Ari Agustina, Fakultas Kesehatan, Universitas Jenderal Achmad Yani Yogyakarta, Jl. Brawijaya Ringroad Barat \\ Ambarketawang Gamping Sleman Yogyakarta. Email : silvia_ari99@yahoo.com
}

\begin{abstract}
Abstrak
IMS merupakan penyakit yang banyak ditularkan meelalui hubungan seksual. Penggunaan pengaman atau kondom saat berhubungan seksual efektif untuk mencegah penyakit ini. IMS banyak menjangkiti kelompok berisiko seperti WPS, akan tetapi belakangan terakhir ini Ibu Rumah Tangga yang notabenenya hanya punya satu pasangan bisa terjangkit penyakit IMS ini. Tujuan dari penelitian ini adalah untuk mengetahui hubungan komponen Health Belief Model (HBM) dengan perilaku penggunaan kondom pada ibu rumau tangga. Metode penelitian yang digunakan dalam penelitian ini adalah mixed methodology dengan strategi eksplanatoris sekuensial. Penelitian ini dimulai dari pengumpulan data kuantitatif terlebih dahulu, setelah selesai untuk memperkuat hasil ditambah dengan data kualitatif. Jumlah sampel untuk data kuantiatif sebanyak 101 responden. Sedangkan untuk data kualitatif melibatkan 2 Ibu Rumah Tangga, 2 Suami, petugas Puskesmas yang melayani penapisan Infeksi Menular Seksual dan 1 Lembaga Swadaya Masyarakat. Analisis yang digunakan adalah regresi linier ganda. Validitas dan reliabilitas data kualitatif menggunakan triangulasi sumber dan metode. Hasil Penelitian terdapat hubungan yang positif dan secara statistik signifikan antara penggunaan kondom dengan beberapa variabel independen yang diteliti. Secara statistik diperoleh hasil yang signifikan adalah variabel persepsi kerentanan (b:-0,12; CI 95\%: -0,23 hingga -0,00; p<0,05), persepsi hambatan kondom (b:-0,11; CI 95\%: -0,22 hingga -0,00; p<0,05), dan efikasi diri (b: 0,19; CI 95\%: 0,10 hingga 0,28; $\mathrm{p}<0,01$ ). Secara bersama-sama seluruh variabel independen di dalam model regresi linier ganda ini mampu menjelaskan perilaku penggunaan kondom sebesar 32\%. Ibu Rumah Tangga sering mengajak suami untuk menggunakan kondom, tetapi suami sering menolak dengan berbagai alasan, misalnya kurang nyaman menggunakan kondom Kata kunci : Health Belief Model; Penggunaan; Kondom
\end{abstract}

\section{Pendahuluan}

Health Belief Model adalah model teoritis yang dapat digunakan untuk memandu promosi kesehatan dan program pencegahan penyakit. HBM digunakan untuk menjelaskan dan memprediksi perubahan individu dalam perilaku kesehatan. HBM menjadi salah satu model yang paling banyak digunakan untuk memahami perilaku kesehatan (RHIHub, 2019).

Konstruksi teori HBM berasal dari teoriteori kognitif dan Psikologi. Harapannya adalah bahwa tindakan kesehatan tertentu dapat mencegah kondisi di mana orang menganggap dirinya berisiko (Wikipedia, 2019; Glanz K R. B., 2015). Teori HBM berpendapat bahwa, pencapaian perubahan perilaku yang optimal jika berhasil menargetkan hambatan yang dirasakan, manfaat, efikasi diri, dan ancaman kesehatan (Jones CL, 2015) . HBM telah diterapkan untuk memprediksi berbagai perilaku yang berhubungan dengan kesehatan seperti screening untuk deteksi dini penyakit dan baru-baru ini telah diterapkan pada beberapa penyakit asimptomatis seperti penyakit kronis dan perilaku seksual berisiko yang berdampak 
pada Infeksi Menular Seksual yang mungkin membutuhkan pemeliharaan perilaku jangka panjang (Wikipedia, 2019; Janz, 1984).

Hal yang paling menarik dari komponen HBM adalah efikasi diri, karena efikasi diri melihat kepercayaan seseorang pada kemampuannya untuk membuat perubahan terkait kesehatan. Kemampuan untuk melakukan sesuatu memiliki dampak yang sangat besar. Bahkan, dalam beberapa tahun terakhir, efikasi diri telah ditemukan menjadi salah satu faktor terpenting dalam kemampuan seseorang untuk berhasil menegosiasikan penggunaan kondom (Boskey, 2019).

$\begin{array}{lll}\begin{array}{c}\text { Penggunaan } \\ \text { mencegah }\end{array} & \begin{array}{l}\text { kondom sangat } \\ \text { penularan }\end{array} & \text { Human }\end{array}$
Immunodeficiency Virus (HIV) serta Infeksi Menular Seksual (IMS). Stigma kondom di Indonesia sebagai alat kontrasepsi semata. Bahkan dilabeli sebagai simbol seks bebas atau praktik prostitusi. Padahal, kondom dan seks bebas tidak memiliki korelasi satu sama lain. Tanpa kondom, seks bebas akan tetap ada, malah jumlah infeksi HIV berisiko semakin meningkat (Putri, 2018).

Ternyata saat ini tidak hanya kelompok berisiko saja yang terjangkit IMS, tetapi Ibu Rumah Tangga yang notabenenya tinggal dirumah dan hanya mempunyai satu pasangan juga beisiko terkena penyakit IMS ini. Hal demikian yang membuat enggang IRT untuk menggunakan kondom, karena merasa aman hanya berhubungan seks dengan satu pasangan saja (Agustina, 2016).

Berdasarkan hal tersebut sangat penting dilakukan penelitian tentang hubungan komponen Health Belief Model dengan penggunaan kondom pada Ibu Rumah Tangga.

\section{Metode}

Metode penelitian yang digunakan dalam penelitian ini adalah mixed methodology dengan strategi eksplanatoris sekuensial. Penelitian ini dimulai dari pengumpulan data kuantitatif terlebih dahulu, setelah selesai untuk memperkuat hasil ditambah dengan data kualitatif. Proses mixing data dalam strategi ini terjadi ketika hasil awal kuantitatif menginformasikan proses pengumpulan kualitatif, sehingga dua jenis data ini terpisah, akan tetapi tetap berhubungan (Susila, 2014).

Jumlah sampel untuk data kuantiatif sebanyak 101 responden. Sedangkan untuk data kualitatif melibatkan 2 Ibu Rumah Tangga, 2 Suami, petugas Puskesmas yang melayani penapisan Infeksi Menular Seksual dan 1 Lembaga Swadaya Masyarakat. Instrumen yang digunakan adalah kuesioner tertutup untuk data kuantitatif, sedangakan panduan wawancara untuk data kualitatif. Kuesioner sebelum digunakan untuk penelitian terlebih dahulu dilakukan uji validitas dan reliabilitas. Analisis yang digunakan adalah regresi linier ganda. Validitas dan reliabilitas data kualitatif menggunakan triangulasi sumber dan metode

\section{Hasil}

Uji asumsi klasik merupakan uji prasyarat apakah variabel yang akan diuji memenuhi syarat untuk dilakukan uji parametrik regresi linier ataukah tidak. Dalam penelitian ini dilakukan uji asumsi klasik sebagai berikut, Uji Multikolinieritas

Tabel 1 Hasil Uji Asumsi Klasik Multikolinieritas

\begin{tabular}{|c|c|c|c|c|}
\hline \multirow[t]{2}{*}{ No } & \multirow{2}{*}{$\begin{array}{l}\text { Variabel } \\
\text { Bebas }\end{array}$} & \multicolumn{2}{|c|}{$\begin{array}{c}\text { Statistik } \\
\text { Multikolinieritas }\end{array}$} & \multirow{2}{*}{$\begin{array}{c}\text { Kesimpul } \\
\text { an }\end{array}$} \\
\hline & & Toleransi & VIF & \\
\hline \multicolumn{5}{|c|}{ Variabel Terikat: Penggunaan Kondom } \\
\hline \multirow[t]{2}{*}{1} & Persepsi & 0,9 & 1,071 & VIF $<10$ \\
\hline & kerentanan & 33 & & \\
\hline \multirow[t]{2}{*}{2} & Persepsi & 0,9 & 1,099 & $\mathrm{VIF}<10$ \\
\hline & Keparahan & 10 & & \\
\hline \multirow[t]{2}{*}{3} & Persepsi & 0,8 & 1,139 & $\mathrm{VIF}<10$ \\
\hline & manfaat & 78 & & \\
\hline \multirow[t]{3}{*}{4} & Persepsi & 0,8 & 1,219 & $\mathrm{VIF}<10$ \\
\hline & hambatan & 21 & & \\
\hline & kondom & & & \\
\hline \multirow[t]{2}{*}{5} & Efikasi diri & 0,8 & 1,240 & $\mathrm{VIF}<10$ \\
\hline & $\begin{array}{l}\text { penggunaan } \\
\text { kondom }\end{array}$ & 06 & & \\
\hline \multirow[t]{2}{*}{6} & Cues to action & 0,9 & 1,112 & $\mathrm{VIF}<10$ \\
\hline & $\begin{array}{l}\text { penggunaan } \\
\text { kondom }\end{array}$ & 00 & & \\
\hline
\end{tabular}


Dapat disimpulkan bahwa model di atas telah terbebas dari adanya multikolinieritas.

Hasil uji Autokorelasi, nilai Durbin Watson variabel penggunaan kondom sebesar 1,99. Jumlah variabel bebas nya adalah 6 dan jumlah sampel nya 101 sampel, maka nilai Dl dan $\mathrm{Du}$ berdasarkan tabel Durbin-Watson yaitu nilai $\mathrm{dL}=1,550$, dan $\mathrm{dU}=1,803$, sehingga dapat ditentukan kriteria terjadi atau tidaknya autokorelasi.

Uji asumsi klasik Heteroskesdatisitas ditunjukkan dari scatter plot berikut ini:

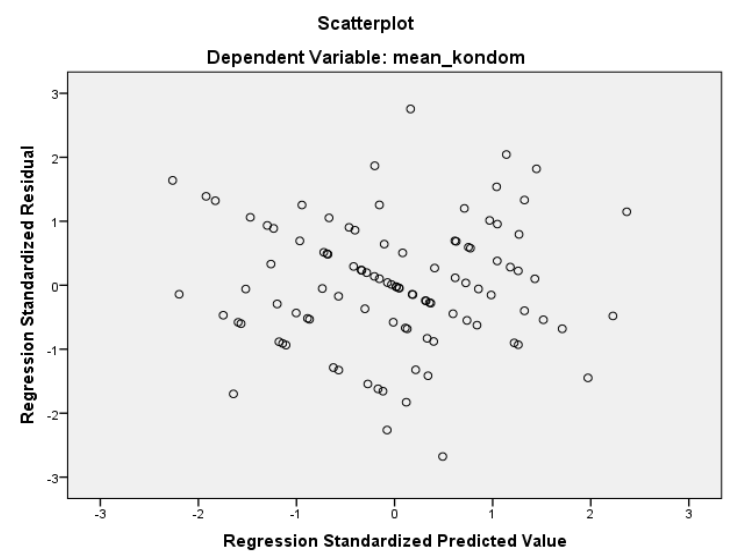

Gambar 1. Scatterplot Residual Penggunaan Kondom

Dalam gambar 4.2 dapat dilihat dari Scatterplot bahwa grafik residual tidak memiliki pola tertetu, yang artinya dalam model tersebut tidak mengalami heteroskesdatisitas.

Uji asusmi klasik yang terakhir adalah uji normalitas. Pengujian normalitas sebaran residu data pada penelitian ini dipergunakan metode Kolmogorov-Smirnov.

Tabel 2. Uji Normalitas Data pada Residu Data

\begin{tabular}{|c|c|c|}
\hline No & Variabel & $\mathrm{P}$ \\
\hline 1. & Persepsi Kerentanan & 0,093 \\
\hline 2. & Persepsi Keparahan & 0,056 \\
\hline 3. & Persepsi Manfaat Kondom & 0,058 \\
\hline 4. & Hambatan & 0,084 \\
\hline 5. & $\begin{array}{l}\text { Kondom } \\
\text { Persepsi } \\
\text { Kondom }\end{array}$ Efikasi Diri & 0,079 \\
\hline 6. & $\begin{array}{l}\text { Persepsi Cues to Action } \\
\text { Kondom }\end{array}$ & 0,072 \\
\hline 7. & Penggunaan Kondom & 0,107 \\
\hline
\end{tabular}

Nilai $\mathrm{P}>0,05$, sehingga dapat disimpulkan bahwa semua variabel terdistribusi normal. Dengan demikian semua variabel lolos uji asumsi klasik, sehingga uji prametrik regresi linier dapat dilakukan.

Tabel 3. Hasil Analisis Regresi Linier Ganda Hubungan antara Komponen HBM dengan Penggunaan Kondom

\begin{tabular}{lcccc}
\hline \multirow{2}{*}{$\begin{array}{l}\text { Variabel } \\
\text { Dependen }\end{array}$} & $\begin{array}{c}\text { Koefisien } \\
\text { Regresi } \\
\text { B }\end{array}$ & $\begin{array}{c}\text { CI 95\% } \\
\text { Lower } \\
\text { Bound }\end{array}$ & $\begin{array}{c}\text { Upper } \\
\text { Bound }\end{array}$ & P \\
\hline Konstanta & 2,62 & 1,99 & 3,25 & $<$ \\
Persepsi & $-0,12$ & $-0,23$ & $-0,00$ & 0,048 \\
$\begin{array}{l}\text { Kerentanan } \\
\text { Persepsi }\end{array}$ & $-0,06$ & $-0,19$ & 0,06 & 0,319 \\
$\begin{array}{l}\text { Keparahan } \\
\text { Persepsi }\end{array}$ & 0,00 & $-0,11$ & 0,11 & 0,958 \\
$\begin{array}{l}\text { Manfaat } \\
\text { Kondom }\end{array}$ & & & & \\
$\begin{array}{l}\text { Persepsi } \\
\text { Hambatan }\end{array}$ & $-0,11$ & $-0,22$ & $-0,00$ & 0,044 \\
$\begin{array}{l}\text { Kondom } \\
\text { Efikasi Diri }\end{array}$ & 0,19 & 0,10 & 0,28 & $<$ \\
$\begin{array}{l}\text { Kondom } \\
\text { Cues } \\
\text { Action }\end{array}$ & 0,11 & $-0,00$ & 0,23 & 0,057 \\
$\begin{array}{l}\text { Kondom } \\
\text { N Observasi }=101\end{array}$ & & & & \\
$\begin{array}{l}\text { Adjusted R } \\
\text { p }<0,001\end{array}$ & & & & \\
\hline
\end{tabular}

Jika dilihat dari nilai Adjusted RSquare yang besarnya 0,320 menunjukkan bahwa proporsi pengaruh variabel persepsi kerentanan, persepsi keparahan, persepsi manfaat kondom, persepsi hambatan kondom, efikasi diri, dan cues to action terhadap penggunaan kondom sebesar $32 \%$. Artinya, persepsi kerentanan, persepsi keparahan, persepsi manfaat kondom, persepsi hambatan kondom, efikasi diri, dan cues to action memiliki proporsi pengaruh terhadap penggunaan kondom sebesar 32\%, sedangkan sisanya 68\% (100\% - 32\%) dipengaruhi oleh variabel lain yang tidak ada didalam model regresi linier. 
Nilai probabilitas $\mathrm{F}$ hitung (sig.) pada tabel di atas nilainya 0,000 lebih kecil dari tingkat signifikansi 0,01 sehingga dapat disimpulkan bahwa model regresi linier yang diestimasi layak digunakan untuk menjelaskan pengaruh variabel independen dengan variabel dependen tersebut diatas.

\section{a. Persepsi Kerentanan dengan Penggunaan Kondom}

Koefisien persepsi kerentanan sebesar -0,12, berarti variabel persepsi kerentanan berpengaruh negatif terhadap penggunaan kondom. Jika persepsi kerentanan mengalami kenaikan, maka akan terjadi penurunan penggunaan kondom sebesar 0,12 dengan variabel lainnya konstan.

\section{b. Persepsi Keparahan dengan Penggunaan Kondom}

Koefisien persepsi keparahan sebesar $-0,06$, berarti variabel persepsi keparahan juga berpengaruh negatif terhadap penggunaan kondom. Namun jika dilihat dari nilai $\mathrm{p}$ value $>0,05$, berarti tidak ada hubungan yang signifikan antara persepsi keparahan dengan penggunaan kondom.

\section{c. Persepsi Manfaat dengan Penggunaan Kondom}

Persepsi manfaat penggunaan kondom tidak berpengaruh signifikan terhadap penggunaan kondom dilihat dari nilai $\mathrm{p}>0,05$ dan diketahui nilai koefisien 0,00 , hal ini berarti tidak ada perubahan yang bermakna jika terjadi penurunan atau kenaikan persepsi manfaat penggunaan kondom terhadap penggunaan kondom. Jadi perubahan persepsi manfaat penggunaan kondom tidak akan memengaruhi perilaku penggunaan kondom.

\section{d. Persepsi Hambatan dengan Penggunaan Kondom}

Koefisien persepsi hambatan penggunaan kondom sebesar $-0,11$, berati variabel hambatan penggunaan kondom berpegaruh negatif terhadap penggunaan kondom. Jika terjadi kenaikan persepsi hambatan penggunaan kondom, maka akan terjadi penurunan sebesar 0,11 perilaku penggunaan kondom.

\section{e. Efikasi Diri dengan Penggunaan Kondom}

Koefisien efikasi diri penggunaan kondom sebesar 0,19, berarti bahwa variabel efikasi diri penggunaan kondom berpengaruh positif terhadap penggunaan kondom. Jika terjadi peningkatan efikasi diri penggunaan kondom sebesar 1 poin, maka akan terjadi peningkatan 0,19 kali perilaku penggunaan kondom.

\section{f. Cues to Action dengan Penggunaan Kondom}

Koefisien cues to action penggunaan kondom sebesar 0,11 , berarti variabel cues to action penggunaan kondom berpengaruh positif terhadap penggunaan kondom. Jika terjadi penurunan cues to action penggunaan kondom, maka perilaku penggunaan kondom juga akan mengalami penurunan sebesar 0,11.

\section{Pembahasan}

Health Belief Model (HBM), merupakan sebuah model perubahan perilaku yang berfokus pada sikap dan keyakinan individu. Menurut Rosenstock, konsep pokok HBM terdiri dari 6 komponen, yaitu persepsi kerentanan, persepsi keparahan, persepsi manfaat, persepsi hambatan, efikasi diri dan cues to action. Salah satu upaya penting dalam pencegahan IMS dan HIV adalah dengan mempromosikan penggunaan kondom untuk hubungan seks berisiko atau hubungan seks tidak aman. Salah satu kegiatan yang dilakukan adalah membagikan kondom gratis kepada populasi berisiko tinggi (Kemenkes, Pedoman Nasional Penanganan Infeksi Menular seksual, 2011). Puskesmas Cangkringan sudah mendistribusikan kondom secara gratis kepada warga yang melakukan kunjungan IMS di Puskesmas Cangkringan. 
Akan tetapi upaya ini belum juga menurunkan angka kejadian IMS secara signifikan setiap bulannya. Hal ini diduga berkaitan dengan persepsi warga terhadap penggunaan kondom yang masih kurang. Sehingga dibutuhkan sebuah perubahan perilaku masyarakat untuk mensukseskan penurunan kejadian IMS di Puskesmas Cangkringan.

\section{a. Persepsi Kerentanan dengan Penggunaan Kondom}

Persepsi kerentanan merupakan tingkat respon atau pendapat responden tentang dirinya rentan atau tidak rentan terhadap IMS, termasuk persepsi tentang konsekuensi spesifik pada resiko dan kondisi yang akan terjadi (mudah/tidak mudah tertular) akibat tindakan seksual yang dilakukan. Hasil penelitian ini menunjukkan bahwa koefisien persepsi kerentanan sebesar $-0,12$, berarti variabel persepsi kerentanan berpengaruh negatif terhadap penggunaan kondom. Jika persepsi kerentanan mengalami kenaikan, maka akan terjadi penurunan penggunaan kondom sebesar 0,12 dengan variabel lainnya konstan. Hasil penelitian ini bertentangan dengan teori yang dikemukakan oleh Taylor (2007) bahwa, semakin tinggi persepsi kerentanan seseorang semakin tinggi pula perilaku pencegahan tertular IMS seperti menggunakan kondom saat berhubungan seksual (Taylor D, 2007).

Hasil wawancara mendalam dengan salah satu IRT Ny. S, mengatakan bahwa Ny. S merasa berisiko tertular setelah mengetahui bahwa suaminya pernah berhubungan seks dengan orang lain. Sehingga Ny. S selalu mengajak suaminya untuk menggunakan kondom saat berhubungan seksual. Akan tetapi suami Ny. $S$ sering menolak menggunakan kondom.

\section{b. Persepsi Keparahan dengan Penggunaan Kondom}

Variabel persepsi keparahan juga berpengaruh negatif terhadap penggunaan kondom. Namun jika dilihat dari nilai $\mathrm{p}$ value persepsi keparahan sebesar 0,319, maka Ho diterima, berarti tidak ada pengaruh yang signifikan antara peresepsi keparahan dengan penggunaan kondom. Jadi dapat disimpulkan bahwa, perubahan persepsi keparahan tidak akan memengaruhi perilaku penggunaan kondom. Hasil ini berlawanan dengan hasil penelitian yang dilakukan oleh Sirait (2013) di Medan, bahwa persepsi keparahan IMS dan HIV memengaruhi perilaku penggunaan kondom (Sirait LM, 2013).

Hasil ini berbeda karena responden penelitian dalam penelitian Sirait (2013) adalah PSK, sehingga mereka lebih menyadari tentang dampak buruk perilaku seksual berisiko yang PSK lakukan (Sirait LM, 2013). Sedangkan dalam penelitian ini respondennya adalah IRT, pengakuan Ny. P yang menganggap bahwa perilaku seksual yang dilakukan selama ini amanaman saja karena hanya melakukan hubungan seksual dengan suami saja, sehingga tidak menggunakan kondom saat berhubungan seks.

\section{c. Persepsi Manfaat dengan Penggunaan Kondom}

Hasil penelitian menunjukkan bahwa, persepsi manfaat penggunaan kondom tidak berpengaruh signifikan terhadap penggunaan kondom dilihat dari nilai $\mathrm{p}=0,958$ dan diketahui nilai koefisien 0,00 , hal ini berarti tidak ada perubahan yang bermakna jika terjadi penurunan atau kenaikan persepsi manfaat penggunaan kondom terhadap penggunaan kondom. Jadi perubahan persepsi manfaat penggunaan kondom tidak akan memengaruhi perilaku penggunaan kondom. Hasil ini juga tidak sesuai dengan hasil penelitian terdahulu, 
bahwa ada hubungan yang signifikan antara persepsi manfaat dengan perilaku penggunaan kondom (Sirait LM, 2013; Barus, 2017; Chandra PA, 2018).

$$
\text { Persepsi manfaat kondom }
$$

(perceived benefits) merupakan penilaian individu mengenai keuntungan yang didapat dengan mengadopsi perilaku kesehatan yang disarankan. Semakin baik persepsi manfaat seseorang terhadap perilaku pencegahan penularan IMS, semakin besar kemungkinan dia akan melakukan tindakan tersebut (Sirait LM, 2013; Barus, 2017; Glanz K R. B., 2008).

\section{d. Persepsi Hambatan dengan Penggunaan Kondom}

Koefisien persepsi hambatan penggunaan kondom sebesar $-0,11$, berati variabel hambatan penggunaan kondom berpegaruh negatif terhadap penggunaan kondom. Jika terjadi kenaikan persepsi hambatan penggunaan kondom, maka akan terjadi penurunan sebesar 0,11 perilaku penggunaan kondom. Hasil ini sesuai dengan pendapat Conner dan Norman (2003), bahwa hubungan perceived barriers dengan perilaku sehat adalah negatif, jika persepsi hambatan terhadap perilaku sehat tinggi maka perilaku sehat tidak akan dilakukan (Conner M, 2003; Mindayani S, 2019).

Hasil wawancara mendalam, IRT mengalami hambatan ketika mengajak suaminya untuk menggunakan kondom, suami sering menolak untuk menggunakan kondom karena merasa kurang nyaman seperti yang diungkapkan oleh Ny. S. Hasil ini sesuai dengan teori yang diungkapkan Kemenkes RI (2009a) dan Mukarom (2012), kondom mempunyai beberapa kekurangan, seperti menganggu kenyamanan bersenggama karena kondom ini mengurangi sentuhan secara langsung saat berhubungan (Kemenkes, Pedoman Pelaksana Lapangan Surveilans Terpadu Biologi dan
Perilaku WPS dan Pria, 2009; Mukarom RS, 2012).

\section{e. Efikasi Diri dengan Penggunaan Kondom}

Efikasi diri atau kemampuan diri yang dimiliki individu untuk dapat mencegah tertularnya IMS. Hasil penelitian menunjukkan, koefisien efikasi diri penggunaan kondom sebesar 0,19, berarti bahwa variabel efikasi diri penggunaan kondom berpengaruh positif terhadap penggunaan kondom. Jika terjadi peningkatan efikasi diri penggunaan kondom sebesar 1 poin, maka akan terjadi peningkatan 0,19 kali perilaku penggunaan kondom. Hasil ini sesuai dengan hasil penelitian yang dilakukan oleh peneliti terdahulu, terdapat hubungan yang signifikan antara dorongan diri atau efikasi diri dengan penggunaan kondom (Sirait LM, 2013; Barus, 2017).

Efikasi diri memengaruhi tindakan seseorang dalam berperilaku menggunakan kondom. Hal ini didasarkan pada keyakinannya untuk mampu melakukan perilaku pencegahan tersebut, semakin tinggi keyakinan diri untuk selalu menggunakan kondom maka perilaku penggunaan kondom akan semakin baik pula. Ny. S mengaku bahwa sulit mengajak suami untuk menggunakan kondom saat berhubungan seksual. Hasil ini berhubungan dengan hasil dari penelitian Widodo (2009), bahwa kesulitan mengajak pasangan untuk memakai kondom meskipun sudah berusaha untuk mengajak, merayu maupun menjelaskanpentingnya memakai kondom, akan tetapi masih banyak pasangan yang tidak mau menggunakan kondom saat berhubungan seksual (Widodo, 2009).

Masih rendahnya kemampuan diri untuk mengajak pasangan menggunakan kondom, berkaitan dengan meningkatnya kejadian IMS. Selain pengakuan dari Ny. 
S, Tn S menguatkan pernyataan tersebut dengan mengatakan bahwa,

"saya merasa kurang nyaman jika berhubungan seksual dengan menggunakan kondom".

\section{f. Cues to Action dengan Penggunaan Kondom}

Koefisien cues to action penggunaan kondom sebesar 0,11 , berarti variabel cues to action penggunaan kondom berpengaruh positif terhadap penggunaan kondom. Jika terjadi penurunan cues to action penggunaan kondom, maka perilaku penggunaan kondom juga akan mengalami penurunan sebesar 0,11. Hasil ini sesuai dengan hasil penelitian terdahulu, bahwa adanya hubungan antara persepsi hambatan dan dorongan dengan perilaku pencegahan penularan HIV/AIDS (Mindayani S, 2019).

Keaktifan mencari informasi melalui teman, petugas kesehatan, penyuluhan, media cetak dan elektronik memengaruhi perilaku penggunaan kondom (Aryani D, 2015). Persepsi individu dari cues to action diharapkan mampu mendorong adopsi perilaku kesehatan jika individu sudah memegang keyakinan kunci lainnya mendukung tindakan. Motivasi kesehatan mengacu pada kestabilan perbedaan antara individu dalam nilai kesehatan dan kecenderungan untuk menjadi termotivasi dalam menjaga kesehatan. Individu dengan motivasi tinggi dalam menjaga kesehatan harus lebih mungkin untuk mengadopsi perilaku kesehatan yang relevan (Conner, 2010).

Hasil analisis multivariat dengan menggunakan regresi linier menunjukkan bahwa IRT dengan persepsi kerentanan, persepsi hambatan dan efikasi diri menggunakan kondom yang tinggi, peluangnya untuk menggunakan kondom kurang baik yaitu sebesar 32\%. Hal ini menunjukkan bahwa persepsi kerentanan, persepsi hambatan dan efikasi diri menggunakan kondom IRT yang tinggi belum sepenuhnya mampu untuk merubah perilaku penggunaan kondom menjadi baik secara keseluruhan.

Ada variabel lain di luar penelitian yang mungkin juga ikut mempengaruhi IRT dalam hal penggunaan kondom. Salah satu contoh variabel yang mungkin mempengaruhi adalah hasrat seksual (libido) pada diri suami IRT itu sendiri. Mudahnya akses WPS dan masih kurangnya pengetahuan serta kesadaran suami untuk melakukan perilaku seksual yang aman. Kondisi seperti ini yang menyebabkan para suami cenderung tidak lagi bisa berpikir normatif, hanya menginginkan kepuasan dalam menyalurkan hasrat seksualnya. Sedangkan kontrol IRT yang kurang saat suami bekerja di luar ruman dan hanya menunggu di rumah, jadi IRT tidak mengetahui aktivitas apa saja yang dilakukan oleh suaminya di luar rumah selain mencari nafkah.

\section{Kesimpulan}

Sebuah teori perubahan perilaku ini terbukti mampu memengaruhi perilaku IRT dalam penggunaan kondom. Ibu Rumah Tangga posisinya adalah korban dari pasangan yang diduga berperilaku seksual tidak aman. Temuan ini memperluas hasil penelitian sebelumnya dan menambah literatur dalam bidang Ilmu Kesehatan Masyarakat.

\section{Referensi}

[1] Agustina, S. (2016). Penerapan Health Belief Model Sebagai Upaya Pencegahan Infeksi Menular Seksual Pada Ibu Rumah Tangga. Media Ilmu Kesehatan, 5(1).

[2] Aryani D, M. N. (2015). Perilaku Pencegahan Infeksi Menular Seksual pada Wanita Pekerja Seksual Kabupaten Tegal. Jurnal Kesehatan Masyarakat. KEMAS, 10(2), 160-168.

[3] Barus, D. (2017). Hubungan Komponen Health Belief Model (HBM) Dengan Penggunaan Kondom Pada Pekerja Seks Komersil (Psk) Di Wilayah Kerja Puskesmas Bandar Baru Tahun 2015. 
Jurnal Mutiara Kesehatan Masyarakat, 15(6), 16-22.

[4] Chandra PA, S. Z. (2018). Analisis Faktor-Faktor Yang Berhubungan Dengan Pemakaian Kondom Dan Pelicin Pada Lelaki Seks Lelaki (Lsl) Sebagai Upaya Pencegahan HIV (Studi Kuantitatif Pada Semarang Gaya Community). Jurnal Kesehatan Masyarakat, 6(1), 791-799.

[5] Conner M, N. P. (2003). Predicting Health Behaviour, Research and Practice with Social Cognition Model. Buckingham: Open Univeristy Press.

[6] Conner, M. (2010). Chapter 2: Cognitive Determinants of Health Behavior. Handbook of Behavioral Medicine. LLC: Springer Science+Business Media.

[7] E, B. (2019, Januari). Health Belief Model Use of a condom may hinge on your perceived risk of STDs. Verywell Mind.

[8] Glanz K, R. B. (2008). Health Behavior and Health Education. Theory Research \& Practice, 49-54.

[9] Glanz K, R. B. (2015). Health behavior: theory, research, and practice (Fifth ed.). San Francisco: Kasisomayajula.

[10] Janz, N. K. (1984). The Health Belief Model: A Decade Later. Health Education \& Behavior, 11(1), 1-47.

[11] Jones CL, J. J. (2015). The Health Belief Model as an Explanatory Framework in Communication Research: Exploring Parallel, Serial, and Moderated Mediation. Health Commun, 30(6), 566-576.

[12] Kemenkes, R. (2009). Pedoman Pelaksana Lapangan Surveilans Terpadu Biologi dan Perilaku WPS dan Pria. Jakarta: Kementerian Kesehatan Republik Indonesia.

[13] Kemenkes, R. (2011). Pedoman Nasional Penanganan Infeksi Menular seksual. Jakarta: Kementerian Kesehatan Republik Indonesia.

[14] Mindayani S, H. H. (2019). Analisis Perilaku Pencegahan Penularan Hiv/Aids Dengan Pendekatan Health Belief Model (Hbm) Pada Wbp Di Lapas Kelas Iia Padang. Jurnal Kesehatan, Edisi Khusus(1), 33-43.
[15] Mukarom RS, W. B. (2012). Gambaran Tingkat Pengetahuan dan Sikap Wanita Tuna Susila terhadap Infeksi HIV/AIDS Di Lokalisasi Kopeng Kabupaten Semarang. Jurnal Kebidanan Panti Wilasa, 3(1).

[16] Putri, A. (2018, Desember). Kondom: Alat Pergaulan Bebas atau Pencegah HIV. Tirto id.

[17] RHIHub. (2019). The Health Belief Model. Rural Health Information Hub: Health Resources and Services Administration (HRSA).

[18] Sirait LM, S. S. (2013). Hubungan konsep Health Belief Model (HBM) dengan tindakan penggunaan kondom pada $\mathrm{ABK}$ pelanggan PSK di Pelabuhan Belawan. Jurnal Precure, 1, 43-49.

[19] Susila, S. (2014). Metode Penelitian Epidemiologi Bidang Kedokteran dan Kesehatan. Yogyakarta: Bursa Ilmu.

[20] Taylor D, B. M. (2007). A Review of the use of the Health BeliefModel (HBM), the Theory of Reasoned Action (TRA), the Theory of Planned Behaviour (TPB) and the Trans-Theoretical Model (TTM) to study and predict health related behaviour change. Department of Health: National institute for Clinical Excellence.

[21] Widodo, E. (2009). Praktik Wanita Pekerja Seksual dalam Pencegahan Penyakit Infeksi Menular Seksual dan HIV/AIDS di Lokalisasi Koplak Grobogan. Jurnal Promosi Kesehatan Indonesia, 4(2). 